\title{
Types of foreign capital inflows and economic growth: new evidence on role of financial markets
}

\begin{abstract}
This paper presents evidences on differential growth effects for three types of foreign capital inflows (foreign direct investment, portfolio equity and debt inflows). Two major results emerged from the application of threshold regression. First, we find strong evidence that the relationship between private foreign capital inflows and growth is characterised by a nonlinear relationship based on financial development. Second, the positive benefits of the three types of capital inflows are only found in countries having a level of financial market development beyond a threshold level. A deeper and more active financial sector is crucial for economic progress.
\end{abstract}

Keyword: Capital inflows; Economic growth; Financial development; Threshold effects 